\title{
The use of the Kahoot Application in Efforts to Increase Student Motivation
}

\author{
Titin Dwi Handayani
}

\author{
SD Negeri Banjaragung 04 \\ titinzaenal45@gmail.com
}

\section{Article History \\ accepted 01/11/2020}

approved 08/11/2020 published 15/11/2020

\begin{abstract}
The purpose of this study was to increase the motivation of students in grade $5 S D$ Negeri Banjaragung 04. This research is a classroom action research (CAR) which was conducted in three cycles, each cycle consisting of planning, implementation, observation, and reflection stages. The subjects of this study were grade 5 students of SD Negeri Banjaragung 04 in the 2020/2021 school year, totaling 23 students. Data collection techniques using observation and questionnaires. Data analysis includes data reduction, data presentation, and drawing conclusions. Research shows that the use of the kahoot application can increase the learning motivation of 5th grade students of SD Negeri Banjaragung 04 for the 2020/2021 school year as evidenced by the percentage of student responses in cycle I there are 10 students with high motivation with a percentage of 43\%, 9 students with moderate motivation with a percentage of $39 \%$, and 4 students whose motivation was low with a percentage of $17 \%$ while in cycle II there was an increase, namely there were 17 students who had high motivation with a percentage of $74 \%$, 4 students who had moderate motivation with a percentage of $17 \%$ and 2 students who low motivation with a percentage of $9 \%$ and in cycle III also experienced an increase, namely there were 21 students with high motivation with a percentage of $91 \%$, and 2 students with a moderate percentage of $9 \%$.
\end{abstract}

Keywords: Kahoot, Motivation, Students.

\begin{abstract}
Abstrak
Tujuan penelitian ini adalah meningkatkan motivasi peserta didik pada kelas 5 SD Negeri Banjaragung 04. Penelitian ini merupakan penelitian tindakan kelas (PTK) yang dilaksanakan dalam tiga siklus, setiap siklus terdiri dari tahap perencanaan, pelaksanaan, observasi, dan refleksi. Subjek penelitian ini adalah peserta didik kelas 5 SD Negeri Banjaragung 04 tahun pelajaran 2020/2021 yang berjumlah 23 peserta didik. Teknik pengumpulan data menggunakan observasi dan angket. Analisis data meliputi reduksi data, penyajian data, dan penarikan kesimpulan. Penelitian menunjukkan bahwa penggunaan aplikasi kahoot dapat meningkatkan motivasi belajar peserta didik kelas 5 SD Negeri Banjaragung 04 tahun pelajaran 2020/2021 yang dibuktikan dengan persentase respon siswa pada siklus I terdapat 10 peserta didik yang motivasinya tinggi dengan presentase 43\%, 9 peserta didik yang motivasinya sedang dengan presentase $39 \%$, dan 4 peserta didik yang motivasinya rendah dengan presentase 17\% sedangkan pada siklus II mengalami peningkatan yaitu terdapat 17 peserta didik yang motivasinya tinggi dengan presentase $74 \%, 4$ peserta didik yang motivasinya sedang dengan presentase $17 \%$ dan 2 peserta didik yang motivasinya rendah dengan presentase $9 \%$ dan pada siklus III juga mengalami peningkatan yaitu terdapat 21 peserta didik yang motivasinya tinggi dengan presentase $91 \%$, dan 2 peserta didik yang motivasinya sedang dengan presentase $9 \%$. Kata kunci: Kahoot, Motivasi, Peserta didik.
\end{abstract}

Social, Humanities, and Education Studies (SHEs): Conference Series https://jurnal.uns.ac.id/shes

p-ISSN 2620-9284

e-ISSN 2620-9292 


\section{PENDAHULUAN}

Belajar adalah suatu proses usaha yang dilakukan oleh seseorang untuk mendapatkan suatu perubahan yang baru sebagai hasil pengalamannya sendiri dalam interaksi dengan lingkungannya. Dalam hal ini, perubahan adalah sesuatu yang dilakukan secara sadar (disengaja) dan bertujuan untuk memperoleh suatu yang lebih baik dari sebelumnya. Tercapainya tujuan belajar dipengaruhi beberapa faktor seperti perhatian dan motivasi. Perhatian mempunyai peranan yang penting dalam kegiatan belajar. Dari kajian belajar pengolahan informasi terungkap bahwa tanpa adanya perhatian tak mungkin terjadi belajar (Gagne dan Berliner, 1984: 355). Disamping perhatian, motivasi mempunyai peranan penting dalam kegiatan belajar. Motivasi adalah tenaga 21 yang menggerakkan dan mengarahkan aktivitas seseorang. Motivasi dapat dibandingkan dengan mesin dan kemudi pada mobil (Gage dan Berliner, 1984: 372).

Kebijakan pemerintah meliburkan sekolah-sekolah merupakan satu langkah yang bijaksana dalam mengatasi penyebaran virus corana. Sekolah bukan diliburkan dalam arti libur tanpa kegiatan melainkan kegiatan belajar harus tetap dilaksanakan dirumah baik secara konvensional maupun belajar daring. Hal tersebut tentunya berdampak pada peserta didik. Guru harus memutar otak dan terus berinovasi agar pembelajaran jarak jauh dapat berjalan dengan efisien dan menyenangkan. sangat penting bagi Guru untuk meningkatkan ketrampilannya dan kemampuannya dalam mengelola pembelajaran jarak jauh. Apalagi pembelajaran jarak jauh ini tergolong hal baru bagi peserta didik maupun guru khususnya pada jenjang sekolah dasar.

Solusi yang coba penulis susun pada laporan ini adalah penggunaan aplikasi berbasis online untuk meningkatkan motivasi dan semangat belajar peserta didik. Salah satu inovasi teknologi agar pembelajaran menjadi kondusif, menarik serta dapat membantu pengajar membuat evaluasi penilaian terhadap peserta didik adalah menggunakan platform kahoot. Kahoot merupakan salah satu alternatif pilihan dari berbagai macam media pembelajaran interaktif yang menjadikan proses pembelajaran menjadi menyenangkan dan tidak membosankan baik bagi peserta didik maupun bagi pengajar karena aplikasi kahoot menekankan gaya belajar yang melibatkan hubungan peran aktif partisipasi peserta didik dengan rekan-rekan sejawatnya secara kompetitif terhadap pembelajaran yang sedang atau telah dipelajarinya. Kahoot dapat mempengaruhi perkembangan sosial emosional anak dalam kemampuan berkompetisi dan berkolaborasi.Berdasarkan uraian di atas, penulis akan melakukan penelitian dengan judul Penggunaan Aplikasi Kahoot dalam Upaya Peningkatan Motivasi Belajar Siswa Kelas V SD Negeri Banjaragung 04 Kabupaten Tegal Semester 1 Tahun Pelajaran 2020/2021. Tujuan penelitian ini Untuk meningkatkan motivasi belajar siswa Kelas V SD N Banjaragung 04 kabupaten Tegal pada pembelajaran jarak jauh dengan menggunakan aplikasi kahoot.

\section{METODE}

Penelitian ini merupakan penelitian tindakan kelas (PTK) kolaboratif yang dilaksanakan dalam tiga siklus. Setiap siklus terdiri dari tahap perencanaan, pelaksanaan, observasi, dan refleksi. Subjek penelitian ini adalah peserta didik Kelas 5 SDN Banjaragung 04 tahun pelajaran 2020/2021 yang berjumlah 23 peserta didik. Data yang dianalisis berupa data kualitatif yaitu penggunaan aplikasi kahoot untuk meningkatkan motivasi belajar peserta didik. Teknik pengumpulan data menggunakan observasi dan angket respon siswa. Uji validitas data menggunakan triangulasi teknik dan triangulasi sumber. Analisis data meliputi reduksi data, penyajian data, dan penarikan kesimpulan. 


\section{PEMBAHASAN}

Berdasarkan analisis hasil penelitian yang telah diuraikan maka pembahasan pada penelitian ini sebagai berikut.

\section{Penerapan Penggunaan Aplikasi Kahoot}

Berdasarkan penelitian tindakan kelas yang sudah dilakukan sesuai dengan langkah-langkah kahoot mengalami peningkatan. Peningkatan dapat dilihat pada tabel berikut.

\section{Tabel 1. Hasil observasi langkah-langkah penggunaan aplikasi kahoot di kelas 5 SDN Banjaragung 04}

Penerapan penggunaan aplikasi kahoot meliputi langkah-langkah: (1) Guru

\begin{tabular}{|c|c|c|c|c|}
\hline No & Aspek yang Diamati & 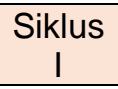 & $\begin{array}{c}\text { Siklus } \\
\text { II }\end{array}$ & $\begin{array}{c}\text { Siklus } \\
\text { II }\end{array}$ \\
\hline 1 & $\begin{array}{l}\text { Guru meminta peserta didik untuk menyiapkan smartphone } \\
\text { guna mengerjakan soal pada kahoot }\end{array}$ & 1 & 1 & 1 \\
\hline 2 & Guru membagikan link kahoot kepada peserta didik & 1 & 1 & 1 \\
\hline 3 & Guru memberikan petunjuk penggunaan kahoot dengan jelas & 0 & 0 & 1 \\
\hline 4 & $\begin{array}{l}\text { Guru memeriksa kesiapan fisik maupun psikis peserta didik } \\
\text { sebelum mengerjakan kuis melalui Kahoot }\end{array}$ & 1 & 1 & 1 \\
\hline 5 & $\begin{array}{l}\text { Guru mempersilahkan peserta didik mengerjakan kuis online } \\
\text { melalui Kahoot }\end{array}$ & 1 & 1 & 1 \\
\hline 6 & $\begin{array}{l}\text { Guru membimbing peserta didik dalam mengerjakan kuis } \\
\text { melalui Kahoot }\end{array}$ & 1 & 1 & 1 \\
\hline 7 & $\begin{array}{l}\text { Guru memberi reward terhadap peserta didik yang telah } \\
\text { menjawab dengan benar }\end{array}$ & 0 & 1 & 1 \\
\hline 8 & $\begin{array}{l}\text { Guru memberi dorongan / motivasi terhadap peserta didik } \\
\text { yang belum tepat dalam menjawab pertanyaan yang } \\
\text { disajikan }\end{array}$ & 1 & 1 & 1 \\
\hline 9 & $\begin{array}{c}\text { Guru menutup kuis dengan semangat } \\
\text { Jumlah } \\
\text { Persentase }\end{array}$ & $\begin{array}{c}1 \\
7 \\
78 \%\end{array}$ & $\begin{array}{c}1 \\
8 \\
89 \%\end{array}$ & $\begin{array}{c}1 \\
9 \\
100 \%\end{array}$ \\
\hline
\end{tabular}

meminta peserta didik untuk menyiapkan smartphone guna mengerjakan soal pada kahoot; (2) Guru membagikan link kahoot kepada peserta didik; (3) Guru memberikan petunjuk penggunaan kahoot dengan jelas; (4) Guru memberi tugas, dengan catatan peserta didik yang kesulitan dalam mengerjakan tugas dapat meminta bimbingan kepada teman yang ditunjuk sebagai tutor oleh guru dan memberikan penjelasan materi yang belum dipahami oleh temannya dalam satu kelompok; (5) Guru mempersilahkan peserta didik mengerjakan kuis online melalui Kahoot. (6) Guru membimbing peserta didik dalam mengerjakan kuis melalui Kahoot; (7) Guru memberi reward terhadap peserta didik yang telah menjawab dengan benar; (8) Guru memberi dorongan / motivasi terhadap peserta didik yang belum tepat dalam menjawab pertanyaan yang disajikan; (9) Guru menutup kuis dengan semangat. Langkah-langkah penggunaan aplikasi kahoot dilaksanakan dalam penelitian ini sejalan dengan penelitian yang dilakukan oleh Rafnis (2019) yang melakukan penelitian dengan topik Pemanfaatan Platform Kahoot Sebagai Media Pembelajaran Interaktif.

Agar lebih jelas, penulis menyajikan tabel 1 hasil observasi penggunaan aplikasi kahoot di kelas 5 SDN Banjaragung 04 ke dalam diagram batang berikut. 


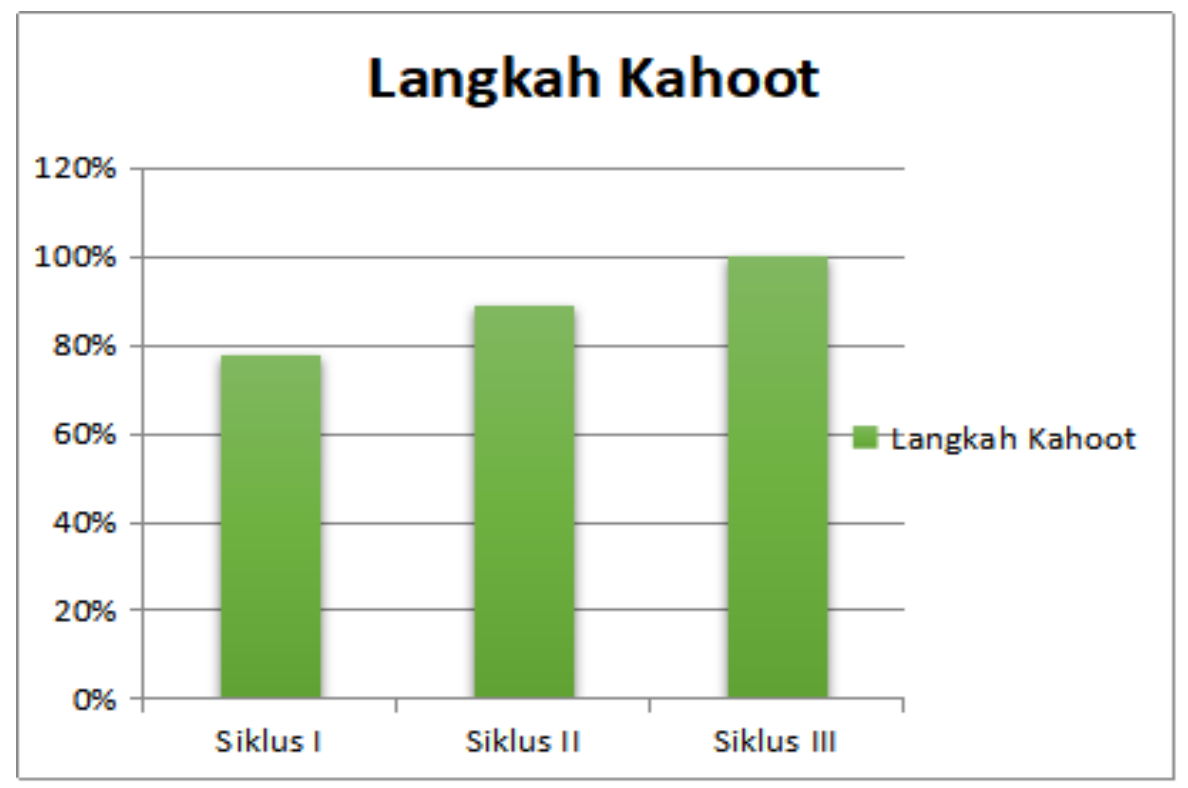

Gambar 1. Hasil observasi langkah-langkah pelaksanaan kahoot pada pembelajaran

\section{Penerapan Kompetensi Motivasi Belajar}

Berdasarkan penelitian tindakan kelas yang sudah dilakukan bahwa motivasi belajar pada peserta didik kelas 5 SD Negeri Banjaragung 04 dengan penggunaan kahoot dapat meningkat. Peningkatan motivasi belajar peserta didik dapat dilihat pada table rekapitulasi respon siswa berikut.

Tabel 2. Rekapitulasi hasil angket respon siswa dengan menggunakan aplikasi kahoot pada kelas 5 SDN Banjaragung 04

\begin{tabular}{cccccccc}
\hline \multirow{2}{*}{$\begin{array}{c}\text { Rentang } \\
\text { Nilai }\end{array}$} & $\begin{array}{c}\text { Tingkat } \\
\text { Motivasi }\end{array}$ & $\mathrm{f}$ & Persentase & $\mathrm{f}$ & Persentase & $\mathrm{f}$ & Persentase \\
\cline { 3 - 8 } & & & & SIKLUS I & \multicolumn{2}{c}{ SIKLUS II } & \multicolumn{2}{c}{ SIKLUS II } \\
\hline $86-100$ & Tinggi & 10 & $44 \%$ & 17 & $74 \%$ & 21 & $91 \%$ \\
$70-85$ & Sedang & 9 & $39 \%$ & 4 & $17 \%$ & 2 & $9 \%$ \\
$<70$ & Rendah & 4 & $17 \%$ & 2 & $9 \%$ & - & - \\
\hline
\end{tabular}

Pada siklus I terdapat 10 peserta didik yang motivasinya tinggi dengan presentase 44\%, 9 peserta didik yang motivasinya sedang dengan presentase $39 \%$, dan 4 peserta didik yang motivasinya rendah dengan presentase $17 \%$ sedangkan pada siklus II mengalami peningkatan yaitu terdapat 17 peserta didik yang motivasinya tinggi dengan presentase $74 \%$, dan 4 peserta didik yang motivasinya sedang dengan presentase $17 \%$ dan 2 peserta didik yang motivasinya rendah dengan prosentase $9 \%$, dan pada siklus III juga mengalami peningkatan yaitu terdapat 21 peserta didik yang motivasinya tinggi dengan presentase $91 \%$, 
dan 2 peserta didik yang motivasinya sedang dengan presentase $9 \%$. Peningkatan motivasi belajar dengan peggunaan kahoot sesuai dengan kajian penelitian yang relevan yang dilakukan oleh Dwi Hartanti (2019) dalam penelitian yang berjudul "Meningkatkan Motivasi Belajar Siswa Dengan Media Pembelajaran Interaktif Game Kahoot Berbasis Hypermedia" dengan hasil bahwa siswa lebih bersemangat dalam belajar dan sangat antusias dalam menggunakan media pembelajaran Kahoot. Dengan Kahoot siswa tertantang untuk menyelesaikan semua pertanyaan dengan harapan selalu ingin berada di peringkat atas.Pada akhirnya mereka dapat lebih mengingat materi pelajaran yang telah diberikan dengan lebih baik setelah menjawab pertanyaan dengan Kahoot.

Agar lebih jelas, penulis menyajikan tabel 1 hasil observasi penggunaan aplikasi kahoot di kelas 5 SDN Banjaragung 04 ke dalam diagram batang berikut.

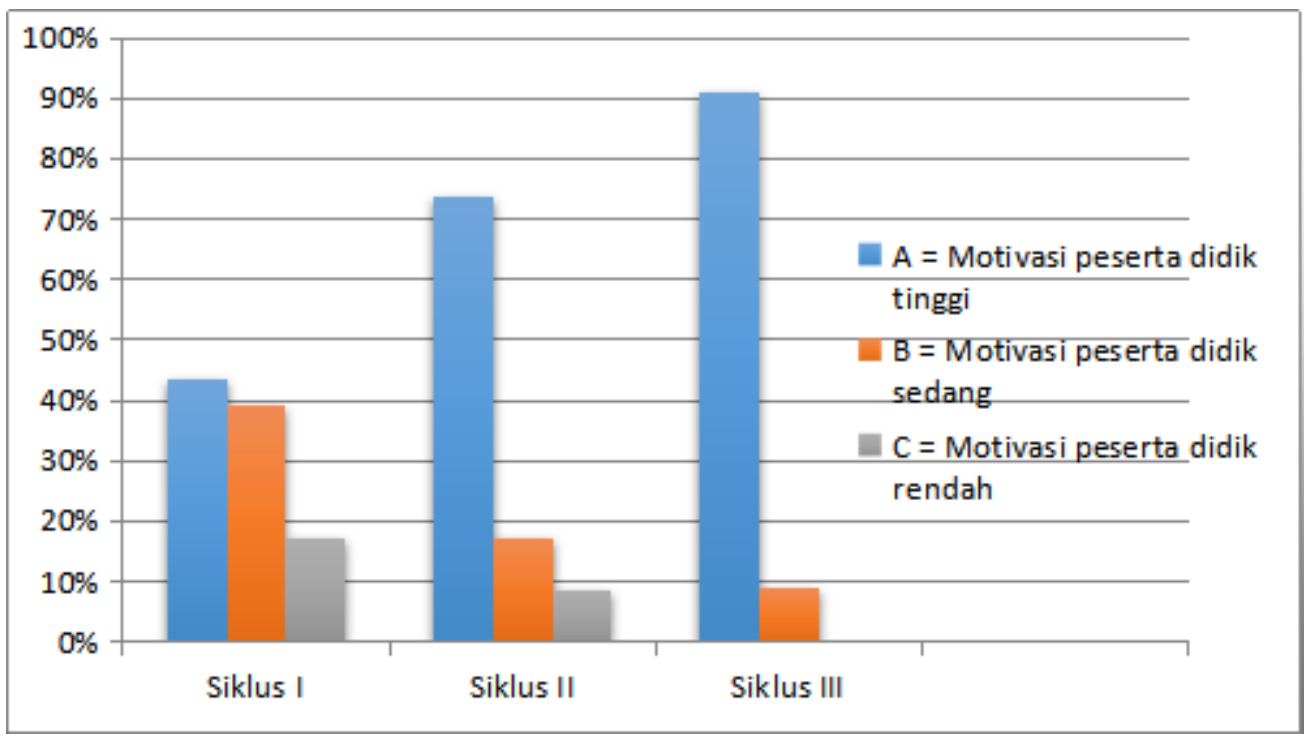

\section{Gambar. 2 Rekapitulasi hasil angket respon siswa dengan menggunakan aplikasi kahoot pada kelas 5 SDN Banjaragung 04}

\section{SIMPULAN}

Berdasarkan penelitian tindakan kelas yang sudah dilakukan dapat disimpulkan sebagai berikut:

1. Melalui langkah - langkah penerapan penggunaan kahoot meliputi guru meminta peserta didik untuk menyiapkan smartphone guna mengerjakan soal pada kahoot, guru membagikan link kahoot kepada peserta didik, guru memberikan petunjuk penggunaan kahoot dengan jelas, guru memeriksa kesiapan fisik maupun psikis peserta didik sebelum mengerjakan kuis melalui kahoot, guru mempersilahkan peserta didik mengerjakan kuis online melalui Kahoot, guru memberi reward terhadap peserta didik yang telah menjawab dengan benar, guru memberi dorongan / motivasi terhadap peserta didik yang belum tepat dalam menjawab pertanyaan yang disajikan, dan guru menutup kuis dengan semangat dapat meningkatkan motivasi belajar pada peserta didik kelas 5 SD Negeri Banjaragung 04 tahun pelajaran 2020/2021. 
2. Melalui penerapan penggunaan aplikasi kahoot dapat meningkatkan motivasi belajar peserta didik kelas 5 SD Negeri Banjaragung 04 yakni ditunjukkan dengan hasil pada siklus I terdapat 10 peserta didik yang motivasinya tinggi dengan presentase 44\%, 9 peserta didik yang motivasinya sedang dengan presentase $39 \%$, dan 4 peserta didik yang motivasinya rendah dengan presentase $17 \%$ sedangkan pada siklus II mengalami peningkatan yaitu terdapat 17 peserta didik yang motivasinya tinggi dengan presentase $74 \%$, dan 4 peserta didik yang motivasinya sedang dengan presentase $17 \%$ dan 2 peserta didik yang motivasinya rendah dengan prosentase $9 \%$, dan pada siklus III juga mengalami peningkatan yaitu terdapat 21 peserta didik yang motivasinya tinggi dengan presentase $91 \%$, dan 2 peserta didik yang motivasinya sedang dengan presentase $9 \%$.

\section{DAFTAR PUSTAKA}

Aqib, Zainal, 2006. Penelitian Tindakan Kelas untuk Guru. Bandung: Yrama Widya.

Doyin, Mukh. 2013. Menulis Artikel Ilmiah \& Populer. Cetakan II. Semarang: Bandungan Institute.

Doyin, Mukh. 2013. Tata Tulis Karya IImiah. Semarang: Bandungan Institute.

Hartanti, Dwi. 2019. Meningkatkan Motivasi Belajar Siswa Dengan Media Pembelajaran Interaktif Game Kahoot Berbasis Hypermedia: Klaten

Safira, Ken. 2014. Model-Model Pembelajaran. Cetakan II. Semarang: Bandungan Institute.

Syarifah, Ety. 2011. Penelitian Pendidikan untuk Guru. Semarang: Bandungan Institute. 